\title{
Contents
}

\section{Guest editorial}

$1 \quad$ Climate change: an emerging health issue

Introduces the articles in this issue, describing the health impacts of climate change and outlining some current actions in response to this emerging health issue.

\section{Anthony G. Capon, Elizabeth G. Hanna}

5 Climate change and health: impacts, vulnerability, adaptation and mitigation

Describes the public health implications of global climate change for Australia and how strategies for mitigation and adaptation can have direct co-benefits for the health of individuals and communities.

Tord Kjellstrom, Haylee J. Weaver

10 Active travel: a climate change mitigation strategy with co-benefits for health

Summarises a number of NSW active travel initiatives as a response to global warming and the increasing imperative to change personal behaviour to slow the rate of climate change.

Chris E. Rissel

14 Functional foods and urban agriculture: two responses to climate change-related food insecurity

Reviews two strategies for dealing with climate changerelated food insecurity and argues that civic and urban agriculture presents an approach that is more connected to factors affecting diet and health.

Jane M. Dixon, Kelly J. Donati, Lucy L. Pike, Libby Hattersley
19 An extreme bushfire smoke pollution event: health impacts and public health challenges

Describes the role of public health in determining the health impact of smoke and the effectiveness of advisories during a severe bushfire smoke event.

Anthony Kolbe, Kim L. Gilchrist

24 Urbanism, climate change and health: systems approaches to governance

Argues for systems approaches and holistic urban governance to effectively address health impacts of climate change and other problems such as the obesity epidemic.

Anthony G. Capon, Emma S. Synnott, Sue Holliday

\section{Bug Breakfast in the Bulletin}

29 Hepatitis A:Wallis Lake revisited

Katina Kardamanidis, Stephen J. Corbett,

Anthony P. Zammitt

\section{Communicable Diseases Report, NSW}

31 November and December 2008

\section{NSW PUBLIC HEALTH BULLETIN}

The NSW Public Health Bulletin is a peer-reviewed journal produced by the NSW Department of Health and indexed in Medline. It has a NSW focus, however, it aims to support the practice of public health more broadly.

\section{Editors}

Dawn Simpson and Caron Bowen

\section{Editorial correspondence}

Please address all correspondence and submissions to:

The Editor, NSW Public Health Bulletin Locked Mail Bag 961

North Sydney NSW 2059 Australia

Email:phbulletin@doh.health.nsw.gov.au

Telephone: +61 294245876

Fax: +61 293919232

\section{Submission of articles}

The Bulletin accepts proffered and commissioned articles along with short reports, on all aspects of public health. Articles should be 1500-2000 words, not including tables and figures, and should include an abstract of up to 100 words. Articles should follow the journal style and layout as closely as possible, as described in the Instructions to Authors. Articles should be emailed in a Word for Windows format to: phbulletin@doh.health.nsw.gov.au, and should be accompanied by a covering letter signed by all authors and a License to Publish. The Instructions to Authors, License to Publish and other useful information can be downloaded from the Bulletin website.

\section{Distribution}

The Bulletin is freely available from the Bulletin website. Copies of the current issue and back issues can be downloaded in both PDF and HTML formats. If you would like to be notified when new issues of the Bulletin are available online, subscribe to the early alert email system at the Bulletin website. The early alert email contains the contents of each new issue along with electronic links to the articles. To receive a printed copy of the Bulletin, subscribe online at the Bulletin website, or contact your local public health unit or the editorial office. eISSN 1834-8610

Website: www.publish.csiro.au/journals/phb Copyright $\odot 2009$ NSW Department of Health 